SEMBLANZA

Rev Chil Salud Pública 2013;

Vol 17 (1): 68-69

\title{
Antonio Cavalla Rojas (1943-2012)
}

El jueves 26 de octubre de 2012 falleció en Santiago, Antonio Cavalla Rojas, más conocido como "Tuco" Cavalla. TUCO, nació en Curicó en 1943. Estudió en el Instituto San Martin de los Hermanos Maristas de Curicó y en el Internado Nacional Barros Arana de Santiago. Era Médico titulado en la Universidad de Chile, además de Cientista Político y Escritor. Fue Presidente del Centro de Alumnos de la Escuela de Medicina y luego Presidente de la Federación de Estudiantes de Chile (FECH) entre 1967 y 1968.

Fue en estas responsabilidades políticas en las que la generación de la reforma universitaria lo conoció y admiró por su compromiso con la transformación de la sociedad, a la que quiso volcar la acción de la institución universitaria. Su compromiso y combatividad se equilibraron siempre con el respeto por las figuras de la intelectualidad chilena que dirigieron la casa de Bello en aquella época. Eugenio González, Juan Gómez Millas, Amador Neghme y otros, supieron de su calidad humana, de su prestancia política y de su generosidad.

El golpe militar de 1973 lo encontró como activo dirigente de la Izquierda Cristiana, partido que contribuyó a formar junto a una pléyade de prestigiados militantes del Partido Demócrata Cristiano. El Tuco nunca dejó de ser médico. Pediatra en la paz y médico de "guerra" en la difícil atención de heridos en los combates de los cordones industriales durante los aciagos días de septiembre de aquel año.

Ya en el exilio, su interés por la cosa pública lo llevó a convertirse en Magister en Ciencia Política en la Universidad Nacional Autónoma de México, de la que fue Profesor e Investigador. Escribió cinco libros y publicó numerosos artículos en Europa, EE.UU. y América Latina. Fue Presidente del Consejo Latinoamericano de Investigadores de la Paz (CLAIP) y Miembro del Consejo del International Peace Research Association (IPRA-Council). Fue co-fundador y Director del Centro de Investigación y Acción en Salud Popular, CIASPO "Padre André Jarlan”, en el que también siguió ejerciendo la pediatría clínica y social.

De nuevo en democracia, lo conocimos como asesor del Ministerio de Salud Pública, en el que los Ministros y Ministras de la Concertación encontraron siempre en él una mirada preclara del acontecer político y una orientación acertada acerca del rumbo que podían y debían seguir las políticas de salud en el difícil mapa

Fernando Muñoz

Escuela de Salud Pública Facultad de Medicina Universidad de Chile fmunoz@med.uchile.cl de actores "incumbentes" de la realidad chilena. En la institución ministerial, los funcionarios más humildes supieron también de su compromiso y desprendimiento. Fue el médico de cuerpo y alma de muchos de ellos y el amigo leal de quienes compartimos con el como jefes y compañeros. 
Pero a la inquietud de Tuco no le bastaba con la salud y la ciencia política. Fue Miembro de la Sociedad de Escritores de Chile (SECH) y publicó varios cuentos en antologías de la Editorial "Ergo Sum" y en la Revista "La Castaña". Fue un permanente colaborador como editorialista en diarios y revistas de Chile y México, en los que enfrentó con valentía a la hipocresía y al prejuicio retardatario de la libertad en el desarrollo de los jóvenes y defendió con fuerza los derechos sexuales y reproductivos.

La muerte lo encontró terminando una historia contemporánea de la FECH. Espero que sea publicada algún día. Era el legado final de un gran médico, un gran político y un enorme ser humano. 